\title{
English Material Needs of Accounting Students: An English for Specific Purposes Approach
}

\author{
Arif Nugroho \\ arifnugroho.iainsurakarta@gmail.com \\ Faculty of Adab and Language, IAIN Surakarta, Indonesia
}

Received: 21 February 2020 Accepted: 9 Mei 2020

DOI: $10.24256 /$ ideas.v8i1.1239

\begin{abstract}
The appropriateness of teaching materials is one of the essential components in gaining the maximum input of knowledge to achieve the success of a language learning. In terms of teaching English for specific purposes, the contextualized material is a prerequisite to encourage the learners' productivity in using the language. Therefore, the present study sheds light on English teaching material needs of accounting students at IAIN Surakarta and the challenges that accounting students face to fulfil the needs. Descriptive qualitative was employed in this study by administering Focus Group Discussion (FGD) and web-based survey to the first-year accounting students who had finished English for Specific Purposes course as the participants. Semi-structured interview was also conducted with the English lecturers and the head of accounting department to enrich the data. The data were analysed by transcribing the results of FGD and semi-structured interview and describing the questionnaire results as data triangulation. The findings of this study showed that contextual English teaching materials are strongly needed by accounting students to enhance their language production. Moreover, there are some insights from the participants related to the ideal teaching materials for accounting students. These findings offer practical insights in designing a representative teaching material for accounting students to equip them with outstanding language skills in accounting field.
\end{abstract}

Keywords: English for accounting; need analysis; teaching materials

\section{Introduction}

The preliminary observation of the teaching English at accounting department of Institut Agama Islam Negeri (IAIN) Surakarta indicated that the English materials slightly fulfilled the students' needs of language skills. It was hypothesized that the language materials was about general English rather than 
English for specific purposes (ESP). Whereas, the English class aimed at assisting the students in developing their skills of language to support their careers in accounting field. In the context of ESP teaching, ideally, the English learning should focus on facilitating the students to develop their language ability based on their own field of studies (Nugroho \& Rekha, 2020). Therefore, the teaching of English must be an opportunity for ESP students to know and acquire the language to assist their professional careers (Poedjiastutie \& Rifah, 2019).

Teaching English for specific purposes remains potentials and challenges in the recent years (Nugroho et al., 2020). Many higher educational institutions such as universities and high schools have offered English for specific purposes program as a compulsory subject which becomes one of the primary areas in English as foreign language (EFL) teaching (Septiyana, 2019; Rokhayati, 2016). According to Basturkmen (2014), ESP is an approach to language teaching where all contents and methods are suitable with the students' reasons for learning. Hence, by referring to the context of the present study, teaching English for accounting should fulfill the students' needs of the language ability in accounting and finance fields.

In the context of teaching English for specific purposes, designing appropriate materials is a prerequisite for an effective learning (Budiharto \& Amalia, 2019). This is the primary stage of a learning process to equip the students with good language competence by offering them representative materials according to their needs and interests (Nugroho, 2019). To ensure the quality of the teaching process, an analysis of the students' basic needs is highly necessary. According to Brown (2016), need analysis is the systematic collection and evaluation of all records that fulfill the students' language necessities and have an effect on their teaching and learning efficacy. Thus, conducting a need analysis is an essential way to develop representative materials for English for specific purposes teaching.

Some previous researchers have conducted need analysis to examine the students' needs and interests in learning English for accounting (Suryadi, 2016; Suprato et al., 2018). Suryadi (2016) examined the target needs and learning needs of English teaching materials for accounting students by involving 46 students of a university in Jambi. The results showed that the students needed specific materials which were closely related with accounting field, especially reading materials to enrich the students' vocabulary about accounting. In a similar direction, Suprato et al. (2018) conducted interview with 54 graduates students from accounting department and several public accounting firms in Jakarta to find out the needs of English teaching materials required by accounting students. The results revealed that English materials focusing on speaking and writing were highly needed by accounting students.

The research of Suryadi (2016), however, involved 46 students and revealed the students' needs of English materials in reading and writing, especially to enhance vocabulary and writing presentation papers. Similarly, the study conducted by Suprato et al. (2018) invited 54 participants to give their perceptions about accounting students' needs of English materials. Since accounting has 
become one of the most-preferred departments nowadays, involving a larger number of accounting students is highly necessary to examine their language material needs and interests. The involvement of greater number of participants will potentially provide more accurate and complete results regarding their English materials needs.

While these previous researches involved 46 and 54 accounting students to examine their materials needs, there is necessary to invite greater number of participants to portray more accurate needs of language materials as required by accounting students. Although the present study involves greater number of participants (147 accounting students), however, its contribution to the realm of English for specific purposes teaching is not the involvement of greater participants. Instead, the current study depicts the challenges of teaching ESP in Indonesian context. This is because investigating the challenges of ESP teaching is crucial to be used as a reference in designing appropriate materials and conducting effective classroom activities. That is why, the present study is carried out to fill the gap by administering focus group discussion and web-based questionnaire to 147 accounting students at IAIN Surakarta as the participants. Semi-structured interview were also conducted with the English teachers and the head of department as data triangulation. To ensure the objectives, this study is guided under the two research questions: (1) what English materials are needed by accounting students? and (2) what are the challenges of teaching English for specific purposes in Indonesia?

\section{Method}

\section{Research Design}

The present study employed descriptive qualitative approach. The views and insights of first-year students of accounting department at IAIN Surakarta were revealed by following this approach. As in a qualitative research, contextualization of the data is an essential aspect of this study (Yin, 2015). Therefore, the data were interpreted only in the context of teaching English for specific purposes at IAIN Surakarta where the data were gathered. This study does not concern on the generalization, but rather on the accuracy of the phenomenon being studied.

\section{Participants}

This study involved 147 first-year students of accounting department at IAIN Surakarta who had finished English for specific purposes (ESP) course in academic year $2019 / 2020$ as the participants. They were amounting to $70 \%$ of the total population and this was accepted to represent the research subjects. According to Fincham (2008), 60\% of the population has met the minimum response rates and in this research context we have $70 \%$. As the supporting data, the researcher conducted semi-structured interview with 3 English for accounting lecturers and the head of accounting department. 


\section{Instruments}

The data of the present study were collected by means of Focus Group Discussion (FGD), web-based questionnaire, and semi-structured interview. The participants who were involved in FGD were conveniently selected without any particular requirement. Convenience sampling which is also called as availability sampling is usually based on the participants' willingness to join in the study (Saunders et al., 2012). By considering the opportunity of each participant to talk and convey her/his perception, the present study had two sessions of FDG with sixteen participants where each session engaged eight students for about 45 minutes. Freitas et al. (1998) states that FGD is a data collection technique that enables researchers in conducting short duration and low budget research. In addition, Birmingham and Wilkinson (2003) reports that this type of data collection provides rich results and in-depth interview since participants can freely communicate with each other in the same time to deal with the same discussion topic.

A web-based questionnaire was also employed to gather the data in this study, particularly for data triangulation of the result obtained from FGD. The total of 147 participants filled out the questionnaire that comprised 15 question items using the Likert scale. The link of the questionnaire was spread by means of WhatsApp, a most-frequently used social media in Indonesia, so it was easy for the participants to participate in this study by filling the required information. According to Weber and Bradley (2006), one of the advantages of collecting data through online platform is affordable and less timely. Several previous studies also recommended that web-based questionnaires are more efficient and fascinating than the conventional methods (Lyons et al., 2005). In addition to the FGD and web-based questionnaire, the researcher also conducted semi-structured interview with three English lecturers teaching at Accounting department and the head of department to reveal their perceptions toward appropriate English materials for accounting students.

\section{Data Collection Procedures}

The study employed an iterative approach in the process of data collection. It is an approach in which some different ways of collecting data are conducted in a predetermined sequence, then connects them based on the main focus of the research (Srivastava \& Hopwood, 2009). In the context of the current study, the FGD was administered at the first stage and then followed by the web-based questionnaire and semi-structured interview. The data collection procedures were presented on the figure below. 


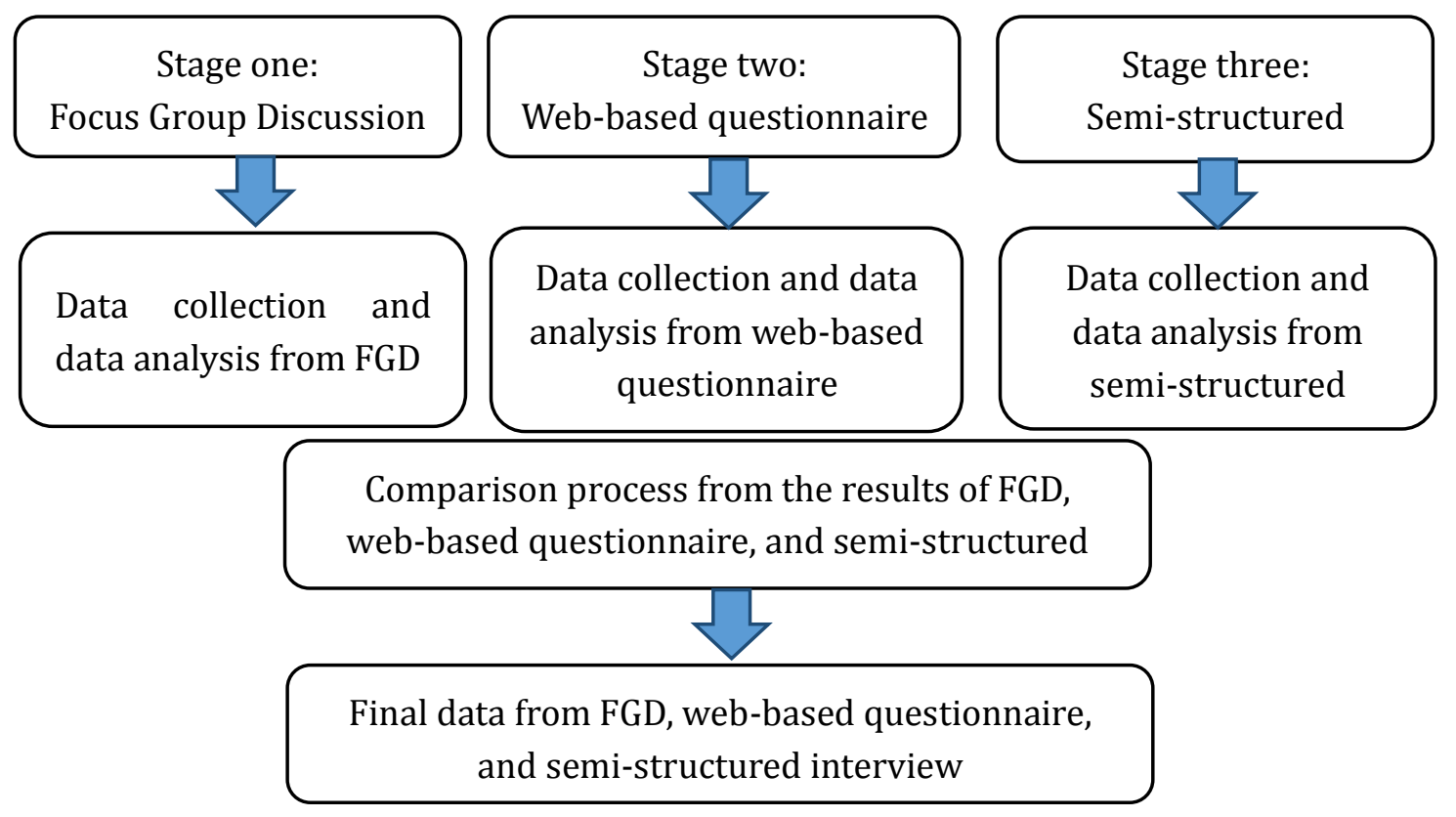

Figure 1. Data collection procedures

\section{Data Analysis}

The data of this study were analyzed in several steps. First, the results of FGD were transcribed. The researcher read the transcription over and over again to obtain the main points. The data were coded to identify the classification and the emerging trends. At the same time, the researcher also removed the repeated and unnecessary data. The classified data then were utilized as the basis of interpretation and conclusion drawing. Second, the questionnaire results were calculated in the form of percentage by using excel program. The percentage aimed to reveal the general perceptions of the participants toward the needs of English materials resulted from FGD sessions. Third, transcribing and coding were also conducted in the process of data analysis from the results of semi-structured interview. Finally, the comparison of FGD, web-based questionnaire, and semi-structured interview results was done before drawing the conclusion.

\section{Results}

This section delineates the findings with regard to the two research questions concerning on the English teaching material needs of accounting students and challenges that accounting students face to fulfil the needs. It also discusses the findings in relation to relevant literature. Several statements of the participant are quoted by translating the participants' words to support the delineation of the findings. 


\section{English Material Needs of Accounting Students}

The Needs of English Materials to Develop Language Skills

Based on the FGD result, the participants stated that all language skills, i.e. speaking, writing, reading, and listening, were needed to enhance their language proficiency.

\section{Participant 3:}

In my opinion, all language skills that are speaking, writing, reading, and listening are very important and should be mastered by accounting students to support them in the working places. And we need to learn materials that cover all the skills, but the materials should be appropriate with the accounting students' needs so that the students will be motivated in learning English.

Among the four skills of English, several participants in the FGD sessions clearly mentioned that speaking was the first skill that should be mastered by accounting students, followed by writing, reading, and listening respectively.

\section{Participant 1:}

Nowadays, the most important skill that should be acquired by employees in this globalization era is the ability to communicate with other people coming from different cultural backgrounds. When we are looking for a job in a reputable company, the interview is usually conducted in English. Therefore we have to possess the ability of speaking in English. Otherwise, we will never obtain a promising job.

This statement was supported by the web-based questionnaire result in which 131, amounting to $89 \%$ of the participants, agreed that oral English communication ability was highly needed to interact with other people or colleagues in the workplace environment. In terms of this topic, the participants perceived that English is undoubtedly important for them to be successful in the future job.

\section{The Needs of English Materials in the Workplace}

A participant in the FGD session described how English played a very important role in the workplace. Based on the sharing experiences with his friends and family, he discovered that the ability of performing good English would determine the employees' future careers. Also, he observed that many good positions in his family's company were occupied by those who possessed good English performance.

\section{Participant 8:}

I found some interesting information during my talk with family and friends who were working in some multinational companies. Most of the employees there such as managers, supervisors, administrators, and workers often use English in daily communication. I think we must enhance our English if we want to work in such reputable companies. 
In terms of English materials in the classroom, most of the participants clarified that the English course slightly provided materials related to accounting during the learning process. Some participants assumed that the teachers had limited understanding of terms and issues about accounting.

\section{Participant 5:}

Our teacher is very good in English, but she rarely touches any Accounting issues. The teacher often teaches us general English materials such as understanding grammar and describing famous people or places. That is why, I do not really enjoy learning in the class.

This was also supported by the result of web-based questionnaire data that revealed only $18(12 \%)$ out of 147 participants agreed that the English teachers slightly equipped them with appropriate materials which fulfilled their needs of English in accounting field. Furthermore, when they were asked what appropriate materials they wanted to learn, most of the participants mentioned that the teaching materials of language skills should be related with accounting such as reading accounting issues, speaking invitation, making phone call, performing job interview, writing financial report, and listening to workplace dialogues.

\section{Participant 11:}

For example in reading, we need to learn passage which was related to accounting field such as accounting jobs, auditing, financial management, etc. In speaking, maybe we learn about how to make a phone call, invitation, formal presentation, and job interview. In writing, we will be happy to learn about writing financial report, curriculum vitae, etc. And in listening of course we need to listen about working environment dialogues.

\section{The Needs of English Materials for Professional Functions}

The results of FGD revealed that there were needs of English materials in order for accounting students to carry out professional activities in workplace environment such as meeting, presentation, writing financial report, and doing job instructions. In the FGDs sessions, the participants clearly stated that English materials, especially speaking, will be very beneficial when later they work in a multinational company where the majority of employees are from overseas. This was in line with the web-based questionnaire results where 137 (93\%) out of 147 participants expressed such opinion.

\section{Participant 13}

I think we need to master the ability of telephoning and making invitation with colleagues. It is because in the workplace we will require to do such activities. And mastering the ability to do presentation is also very important. Even for business activities like negotiation and marketing need good speaking skill, especially in English.

The participants also explained that good English assists them to avoid misunderstanding. Accountants should be able to carry out instructions in English 
so that there will not be misunderstanding. This statement was from the participants in the FGD who said that the ability to communicate in English can result in the success or failure of projects or business.

\section{Participant 1:}

We can imagine when accountants experience misunderstanding from their boss or supervisors. It will lead to the failure of a project or work.

\section{The Needs of English Materials for Casual environment}

The participants stated that English was needed not only for professional functions but also for informal functions in day to day communication inside and outside of the workplace. They need English to interact with colleagues, staffs, team, supervisors, and even with their boss.

\section{Participant 16:}

English is also needed when working in informal setting. For example when we have to accompany our managers or supervisors for work outside the office, we should perform very good skill in English both for technical and non-technical skills.

This opinion was supported by the data from questionnaire which revealed $121(82 \%)$ out of 147 participants stated that English was needed to communicate easily in informal situation.

\section{The Needs of English materials for Vocabulary Acquisition}

There was a need for English materials that facilitated the participants to enhance the acquisition of vocabulary, especially terms and words in accounting field. During the FGD sessions, the participants uttered that vocabulary was the heart of language acquisition. Without vocabulary mastery, the students would not be able to produce utterances in speaking and writing as well as could not receive information from reading and listening.

\section{Participant 14:}

Another important element that should be mastered by us is vocabulary. Sometimes, we cannot memorize vocabulary because it is so boring. That is why, in my opinion, we need English materials that force us to acquire vocabulary through some interesting learning activities.

This assertion was supported by the result of web-based questionnaire in which 140 (95\%) out of 147 participants stated that the acquisition of vocabulary was the most essential to perform the four language skills. Moreover, this statement was also emphasized by the English teacher. The result of semi-structured interview with the teachers revealed that the students were lack of vocabulary acquisition, therefore, they needed materials that could enrich their vocabulary memorization. One of the English teachers said: 


\section{Teacher 1:}

I realize that my students' vocabulary acquisition is still low. It affects their English abilities, especially the production of speaking and writing. In the class, actually I have provided them with some activities to improve their vocabulary. However, I realize that sometimes I give the vocabulary that is not quite related with accounting. Thus, in my opinion, materials to enhance students' vocabulary acquisition are urgently needed so that we can use them to teach the students.

\section{The Challenge of ESP Teaching in Indonesia}

Teaching Approach and Materials

The results of FGD sessions indicated the majority of the participants mentioned that the English course was slightly different with general English course. According to them, the materials learned in the classroom did not reflect their needs of English for accounting field.

\section{Participant 6:}

I totally do not understand terms and vocabulary related to accounting because when I read a passage about accounting I do still not understand the content. Sometimes, I need to look at my dictionary for the meaning of certain words. In my opinion, the English class, which is only given in the first semester, should provide insights and materials that are closely related with our field of study.

A participant in the FGD added that she felt learning general English during her involvement in the English class. The materials given by the teacher did not focus on accounting.

\section{Participant 9:}

Based on my experience joining English class last semester, I feel that I do not learn about English for accounting, rather the general English. I think we need English materials that are specially designed to meet our needs of English for accounting and finance fields.

Moreover, some participants expressed suggestions to sum up what had been said by their friends about the ideal way of teaching English and the proper teaching materials for accounting students.

\section{Participant 10:}

For me, English class should give us the materials which closely related to accounting. For example, like my friends' previous saying, reading text about the nature of accounting, accounting jobs, auditing, financial management, entrepreneur, etc. 
One of the participants added,

\section{Participant 13:}

I think speaking is the most important one. In speaking we can learn about how to introduce ourselves in working environment, how to make invitation, how to present idea and opinion, and how to deal with job interview. And for writing skill, maybe the most urgent is we have to learn about writing financial report, writing a good curriculum vitae, or writing an application letter.

The issue of inappropriate teaching materials in English class was clearly supported by the result of questionnaire and semi-structured interview. The questionnaire result revealed that 127 (86\%) out of 147 participants agreed that the English class should provide them with English teaching materials which related to accounting and finance or at least to business environment. The results of semi-structured interview with the English teachers and the head of accounting department also indicated the similar idea. One of the English teachers added that they were difficult to find appropriate materials to teach English for accounting students. Similarly, the head of accounting department confirmed that the English materials for accounting students had not been developed.

\section{The Duration of English Course}

During the FGD, the participants had different views about the duration of English course. A participant specifically stated that the duration of time would not be a problem if the materials met the students' needs of language skills.

\section{Participant 5:}

I think the success of the English class do not depend on the duration of the course, but rather on the accuracy of the materials. I mean the materials must be relevant with our needs and field of study, which is accounting. Although it is only one semester, it will be very effective and efficient if the learning materials are good.

Meanwhile, most of the participants argued that the duration of English class was less long that it should be. Learning English in a semester and only 3 credits was not sufficient. According to them, it was due to acquiring English needed a lot of practices and habits. For the students, the more they practice the better their acquisition.

\section{Participant 3:}

For me, learning a language needs a lot of practices. My teacher said that the more we practice, the better our acquisition of a language, including English. That is why, I think the duration of the English class have to be added. 3 credits in one semester will be not enough. We need more time. 
The duration of teaching English affected the effectiveness of the course. This assertion was supported by the data of questionnaire in which 113 (76\%) out of 147 participants asserted that the duration of teaching English for accounting students needed to be extended. However, they did not have any idea how long the ideal duration for the teaching English. Furthermore, the English teachers who taught at accounting department also stated that they needed longer duration of time to ensure the efficacy of the English teaching and learning. One of the English teacher said:

\section{Teacher 3:}

I do agree that teaching English for accounting students in one semester is not enough. In fact, we are difficult to deliver the materials comprising the four skills to the students.

\section{Discussion}

These findings indicate that accounting students at IAIN Surakarta need representative English materials which reflect their field of study to support their academic success and career development. Moreover, they, along with the English teachers and the department, have to deal with some challenges of teaching English for accounting in Indonesian context. In terms of teaching English for accounting, the results of this study are similar with the findings of Suryadi (2016) and Suprato et al. (2018). However, the present study reveals some facts that have not been found by the previous researches.

In the work of Suryadi (2016), he specifically looked at the needs of accounting students at a state university in Jambi, Indonesia. He gathered the data by means of target needs and learning needs questionnaire from 46 students of accounting department. According to the research, specific materials in learning English which are closely related to the study program are highly needed by the students. The research also revealed that English skills should be combined with the knowledge of accounting, especially reading for enhancing the students' vocabulary in accounting.

Similarly, Suprato et al. (2018) evaluated English materials and syllabus of accounting department in Bina Nusantara University. They earned the data by interviewing 54 university graduates from accounting department and public accountant firms in Jakarta. The results showed that the accounting students needed specific English materials to improve their language skills. However, while Suryadi's (2016) result showed that reading skill was the priority, Suprato's et al. (2018) study indicated that there was a need to provide oral communication training to the accounting students.

Apart from all of these previous findings, the current study showed some differences. First, there was new information about accounting students' needs of English materials which has not been revealed by the previous studies, that is the needs of English for contextualized workplace environment in accounting field. The FGD, questionnaire, and semi-structured interview found that the accounting 
students needed representative English materials that specifically discussed about accounting and finance to equip them with adequate professional skills of language. The participants reported that many of accountants, especially in reputable and multinational companies, would often use English in their daily communication. Furthermore, well acquisition of English will potentially support their career development in the working environment. Therefore, English materials about working environment in accounting field should be developed to equip the students with excellent language skills in their professional careers.

The second difference is the challenges of English for specific purposes teaching in Indonesia. The result of data analysis indicates that teaching materials and the duration of the English course need to be evaluated. The participants both students and teachers are aware that more representative English materials should be developed. Also, the duration of the English course should be extended. The main purpose of offering ESP program for accounting students was to get students ready in globalization era. This is supported by Chmelíková and Hurajová (2019) who state that ESP is a program for developing students' English skills based on the needs of their study field. However, the purpose of ESP program was in contrast with what had been found in the present study. Most of ESP teachers taught general English rather than specific English. This is in line with the statement of Puspa et al. (2018) which declare that one of the teaching ESP challenges in Indonesia is the lack of representative materials to meet the students' English needs.

Another challenge of Indonesian ESP teaching is the short duration of the course. The result of data analysis implicates that the duration of the ESP program should be extended. Both students and teachers who were involved in this study confessed that learning English for accounting in one semester with 3 credits was not enough. This might be caused by most of ESP programs in Indonesian universities are usually offered only for the first-year students. This finding completes what has been found by Marwan (2017) that concludes some factors influencing the efficacy of ESP teaching and learning, i.e. motivation, curriculum and students' English proficiency, learning resources, and teachers' capacity. The finding of this study is also similar with Dardjowidjojo (2000) and Yuwono and Harbon (2010).

Considering all of these, the results of the present study have contribution to the realm of teaching English for specific purposes in Indonesian context. First, this study offers the students' needs of language skills for ESP teachers, especially those who teach English for accounting, and therefore they will be able to design appropriate materials. Second, the findings of this study could be used as alternative reference to develop curriculum and syllabus of English course for accounting students. Thus, the students will learn English materials that fulfill their needs and interests. Last but not least, it is strongly recommended that the results of this study are used as a basic reference to design a practical book or module that will assist accounting students in enhancing their language skills. Hence, ESP 
course can be considered as a preparation class to develop their English proficiency both in academic achievement and in the future professional career.

\section{Conclusion}

Drawing on the findings and discussion, it is obvious that accounting students of IAIN Surakarta urgently need representative English materials to meet their needs of language proficiency in academic and professional career. In detail, they need English materials for working environment, for professional function, for casual environment, and for vocabulary acquisition. Moreover, the present study also reveals two challenges of teaching ESP in Indonesian context, that are teaching approach and materials and short duration of the course. The findings of the current study provide practical contribution to the realm of English for specific purposes teaching in offering the more accurate delineation of accounting students' needs of English. Thus, appropriate English materials for accounting students should be designed by referring to the findings of this study. However, it must be noted that the contextualization of this present study could not represent the overall accounting students' needs of language skills. Therefore, the author suggests an immense project in similar issues should be conducted by involving a greater number of participants coming from different institutions. Finally yet importantly, improving the quality of ESP teaching should be continuously developed to ensure the students' success of language learning in both academic achievement and future professional career.

\section{Acknowledgement}

Many thanks and acknowledgement go to all participants of the present study, i.e. first-year students, English teachers, and head of department of sharia accounting of Institut Agama Islam (IAIN) Surakarta.

\section{References}

Basturkmen, H. (2014). Ideas and options in English for specific purposes. Routledge. Birmingham, P., \& Wilkinson, D. (2003). Using research instruments: A guide for researchers. Routledge.

Brown, J. D. (2016). Introducing needs analysis and English for specific purposes. Routledge.

Budiharto, R. A., \& Amalia, L. (2019). Motivation Behind Indonesian Undergraduates Learning English As a Target Language. IDEAS: Journal on English Language Teaching and Learning, Linguistics and Literature, 7(1). 
English Material Needs of Accounting Students: An English for Specific Purposes Approach

https://doi.org/10.24256/ideas.v7i1.714

Chmelíková, G., \& Hurajová, L. (2019). Esp Teachers in the World of Globalisation and Higher Education Internationalisation. Journal of Teaching English for $\begin{array}{llll}\text { Specific and Academic Purposes, } & \text { 7, }\end{array}$ https://doi.org/10.22190/jtesap1904443c

Dardjowidjojo, S. (2000). English teaching in Indonesia. EA Journal, 18(1), 22-30.

Fincham, J. E. (2008). Response rates and responsiveness for surveys, standards, and the Journal. American Journal of Pharmaceutical Education, 72(2).

Freitas, H., Oliveira, M., Jenkins, M., \& Popjoy, O. (1998). The Focus Group, a qualitative research method. Journal of Education, 1(1), 1-22.

Lyons, A. C., Cude, B., Lawrence, F. C., \& Gutter, M. (2005). Conducting research online: Challenges facing researchers in family and consumer sciences. Family and Consumer Sciences Research Journal, 33(4), 341-356.

Marwan, A. (2017). ESP teaching challenges in an Indonesian vocational higher institution. The English Teacher, 12.

Nugroho, A. (2019). Request Realizations of Indonesian Esp Lecturers. A Journal of Culture English Language Teaching Literature \& Linguistics, 6(1), 1. https://doi.org/10.22219/celticumm.vol6.no1.1-13

Nugroho, A., \& Rekha, A. (2020). Speech Acts of Requests: A Case of Indonesian EFL Learners. Journal of English Language Teaching and Linguistics, 5(1), 1-16.

Nugroho, A., Zamzami, M. R. A., \& Ukhrowiyah, N. F. (2020). Language input, learning environment, and motivation of a successful EFL learner, Journal on English as a Foreign Language (JEFL ), 10(1), 46-69.

Suryadi. (2016). English for Specific Purposes for Accounting Students. 3(2), 144-148.

Poedjiastutie, D. (2019). English Communication Needs of Engineering Students. International Journal of Language and Linguistics, 7(2), 69. https://doi.org/10.11648/j.ijll.20190702.13

Puspa, A., Latief, M. A., \& Iragiliati, E. (2018). English for Academic Purposes: E-Module of Writing a Report for Food Processing Technology Students. Jurnal Pendidikan, 3(3), 371-376.

Rokhayati, T. (2016). Intercultural Approach and Character Education- Based Developing English Textbook. English Review: Journal of English Education, 5(1), 131. https://doi.org/10.25134/erjee.v5i1.393

Salija, K., \& Makassar, U. N. (n.d.). Needs Analysis of English Materials for Accounting Study Program.

Saunders, M., Lewis, P., \& Thornhill, A. (2012). Business research methods for business students. Harlow: Pearson Education Ltd.

Septiyana, L. (2019). Designing English Speaking Materials Using Task- Based Language Teaching (Tblt) for Islamic Economics Students. IDEAS: Journal on English Language Teaching and Learning, Linguistics and Literature, 7(2), 154-163. https://doi.org/10.24256/ideas.v7i2.1031

Srivastava, P., \& Hopwood, N. (2009). A practical iterative framework for qualitative 
IDEAS, Vol. 8, No. 1, June 2020

ISSN 2338-4778 (Print) ISSN 2548-4192 (Online)

data analysis. International Journal of Qualitative Methods, 8(1), 76-84.

Suprato, D., Dewi, I. I., \& Paulina, C. (2018). English Syllabus for Accounting Students and the Needs of English in Business World. Lingua Cultura, 12(2), 129. https://doi.org/10.21512/lc.v12i2.2068

Weber, J. A., \& Bradley, K. D. (2006). Strengths and weaknesses of conducting web-based surveys: A review of the literature. Mid-Western Educational Research Association Annual Meeting.

Yin, R. K. (2015). Qualitative research from start to finish. Guilford publications.

Yuwono, G. I., \& Harbon, L. (2010). English teacher professionalism and professional development: Some common issues in Indonesia. Asian EFL Journal, 12(3), 145-163. 